\title{
PENGARUH EFISIENSI BIAYA PERBANKAN DI KAWASAN ASEAN- 5
}

\author{
Tamitha Intasar Husen, SE, MBA \\ Tamita.husen@gmail.com \\ Universitas Teuku Umar
}

\begin{abstract}
This study examines determinants of cost efficiency of banking operation in ASEAN-5 region which includes Indonesia, Singapura, Malaysia, the Philippines, and Thailand. By using stochastic frontier analysis (SFA) to 23 commercial banks in the region in the period of 2005-2012, empirical results reveal certain significant relationship of cost efficiency with individual bank characteristic (return on equity, ROE). Based on the time-varying decay method, we conclude that there is an increase in cost efficiency during the period of study. This study also shows that in general, Indonesian banking industry was not operating efficiently.
\end{abstract}

Keywords: ASEAN-5, cost efficiency, banking, SFA, time-varying decay

\section{Pendahuluan}

Perbankan merupakan salah satu sektor yang sangat penting di dalam struktur keuangan di suatu negara. Sektor perbankan masih menjadi bentuk utama intermediasi keuangan dan menjadi sumber utama terhadap permodalan eksternal bagi perusahaan maupun pihak-pihak yang membutuhkan permodalan untuk menjalankan bisnisnya (Mishkin 2001). Peran tersebut lebih terlihat pada struktur keuangan di negara berkembang termasuk Indonesia. Data Bank Indonesia tahun 2013 menunjukkan bahwa industri perbankan masih mendominasi sistem keuangan di Indonesia dengan pangsa sekitar 77.9 persen dari total aset lembaga keuangan. Pentingnya peran sektor perbankan mengharuskan perbankan untuk terus menjaga kinerjanya dengan baik.

Kiner ja perbankan yang rendah akan menyebabkan sektor produktif kekurangan dana sehingga akan menghambat produksi yang dapat menyebabkan terhambatnya pertumbuhan ekonomi suatu negara. Kinerja perbankan salah satunya dapat diukur melalui efisiensi. Inefisiensi perbankan merupakan salah satu indikator yang menunjukkan rendahnya kinerja perbankan. Efisiensi dan kesehatan perbankan dipandang sebagai sebuah keharusan. Hal tersebut ditujukan untuk menciptakan stabilitas sistem keuangan. Bank yang inefisien dan tidak sehat secara individual, dapat melemahkan sistem keuangan melalui bunga pinjaman yang tinggi.

Indonesia merupakan salah satu negara di kawasan ASEAN yang masih memiliki tingkat suku bunga yang tinggi baik pada suku bunga simpanan maupun suku bunga kredit.. Suku bunga rata-rata untuk simpanan berjangka dan kredit perbankan Indonesia pada September 2014 masing-masing sebesar 9.04\% dan $12.84 \%$. Tingkat suku bunga kredit dan deposito Indonesia masih lebih ting gi 
dibandingkan negara lainnya di kawasan ASEAN seperti Singapura, Thailand, Malaysia, dan Filipina. Sebagai contoh, pada tahun 2012 suku bunga deposito 3 bulan di Indonesia sebesar 5.76\% lebih besar dari Singapura (0.14\%), Malaysia $(2.97 \%)$, dan Philipina (3.03\%). Begitupun halnya dengan tingkat suku bunga kredit, minimum lending rate Indonesia sebesar $11.49 \%$ lebih tinggi dari Malaysia, Philipina, dan Singapura dengan nilai berturut-turut $6.53 \%, 5.48 \%$, dan $5.38 \%$. Tingkat suku bunga nominal yang semakin tinggi akan meningkatkan beban bunga bank dan pada akhirnya akan menurunkan tingkat efisiensi melalui ketidakpastian dan risiko yang lebih besar (Fries dan Taci, 2005). Sektor perbankan di kawasan ASEAN-5 akan menghadapi integrasi finansial dan perbankan yang akan diimplementasikan pada tahun 2020 .

Kehadiran integrasi tersebut diharapkan dapat meningkatkan daya saing sektor perbankan di kawasan ASEAN-5 di industri perbankan internasional. Hal ini disebabkan proses integ rasi mampu mengurangi tingkat inefisiensi terutama pada sisi biaya perbankan (Ferreira, 2011). Akan tetapi, kehadiran integrasi sektor perbankan juga menjadi ancaman bagi industri perbankan domestik. Adanya integrasi tersebut memberikan kemudahan bagi bank-bank asing untuk masuk ke dalam industri perbankan nasional. Kemunculan bank-bank asing tersebut akan menciptakan kondisi persaingan pasar perbankan nasional semakin ketat dan ketahanan bank-bank domestik akan diuji. Kegagalan bank domestik dalam persaingan berpotensi memberikan efek negatif pada kondisi perekonomian negaranya.

Penelitian mengenai efisiensi biaya telah banyak dilakukan dimana metode umum yang digunakan adalah stochastic frontier analysis (SFA) seperti pada kajian Fries dan Taci (2005), Kosak, Peter, dan Jelena (2009), Irsova (2010), dan Bonin, Hasan, dan Wachtel (2005). Sebagian besar penelitian-penelitian tersebut dilakukan dengan ruang lingkup wilayah Eropa (Fries dan Taci, 2005; Kosak, et al. 2009; Irsova, 2010; dan Banerjee, 2012). Hasil Kajian Fries dan Taci (2005) dengan fokus pada status kepemilikan bank salah satunya menunjukkan bahwa bank swasta di 15 negara Eropa Timur memiliki kinerja efisiensi biaya yang lebih baik dibandingkan bank milik pemerintah.

Sejalan dengan itu, Banerjee (2012) melihat status kepemilikan antara asing dan domestik. Hasilnya memperlihatkan bahwa kepemilikan asing (foreign ownership) berpengaruh signifikan dan memiliki hubungan positif dengan efisiensi biaya. Artinya bank yang dimiliki oleh pihak asing memiliki tingkat efisiensi biaya yang lebih tinggi.

Bonin, et al. (2005) juga menganalisis pengaruh kepemilikan bank terhadap kinerja bank yang dalam hal ini diukur dengan efisiensi biaya dan efisiensi profit.

Hasil penelitian ini menunjukan bank asing memiliki efisiensi biaya dan efisiensi profit yang lebih tinggi, tetapi ukuran suatu bank yang diukur dari total asset memberikan dampak negatif terhadap efisiensi bank itu sendiri. Sementara itu, dengan memasukkan unsur tingkat kompetisi perbankan, Kosak, et al. (2009) menggunakan Hirchsman-Herfindahl Index (HHI).

Hasilnya menunjukkan bahwa HHI tersebut memiliki peran yang sangat penting dalam memengaruhi tingkat efisiensi perbankan dibandingkan variabel lainnya. 
Sementara di ASEAN sendiri, kajian efisiensi bank pernah dilakukan oleh Karim (2001) dan Tahir, Mongid, dan Haron (2012). Karim menemukan bahwa bank-bank besar di kawasan ASEAN memiliki kecenderungan tingkat efisiensi yang lebih tinggi dibandingkan dengan bank yang lebih kecil. Kesimpulan dari kajian Tahir,et al . (2012) antara lain menemukan bahwa bankbank diSingapura memiliki cost inefficiency yang rendah dibandingkan negara lainnya di kawasan ASEAN. Berdasarkan faktor-faktor yang memengaruhinya, inefisiensi biaya perbankan di kawasan ASEAN lebih dipengaruhi oleh variabel internal bank dan pertumbuhan ekonomi. Inefisiensi biaya juga dipengaruhi oleh tingkat korupsi dan kebebasan ekonomi, namun tidak terjadi di semua negara. Di Indonesia sendiri ukuran efisiensi bank secara deterministik menggunakan BOPO (biaya operasional dibagi dengan pendapatan operasional). Rini (2008) menemukan bahwa untuk kajian dengan ruang lingkup di negara Indonesia saja rata-rata efisiensi yang diukur berdasarkan metode SFA maupun BOPO dari 2005 - 2007 memberikan hasil yang serupa.

Meskipun demikian, menurut Mediadianto (2007) terdapat perbedaan interpretasi antara kedua metode pengukuran tersebut, dimana metode SFA/DFA memiliki pengukuran yang lebih konsisten karena merupakan rincian dari variabel perhitungan rasio keuangan termasuk didalamnya ada komponen BOPO. Pendekatan cost frontier mengukur seberapa jauh suatu industri dalam hal ini bank dengan full-cost minimization yang diukur secara relatif terhadap bank lain. Dalam hal ini ruang lingkup pada kajian ini adalah bank-bank di negara ASEAN5, sehingga membandingkan efisiensi menggunakan metode parametrik SFA lebih relevan dibandingkan dengan perhitungan BOPO.

Penelitian ini bertujuan untuk menganalisis tingkat efisiensi biaya perbankan di kawasan ASEAN - 5 dan faktor-faktor yang memengaruhi tingkat efisiensi biaya tersebut. Kawasan ASEAN-5 ini dipilih mengingat lima negara di dalamnya memiliki perekonomian terbesar di wilayah ASEAN. Selain itu, masyarakat ekonomi ASEAN (MEA) juga diinisiasi oleh kelima negara tersebut. Pada kajian ini, periode yang digunakan mencakup terjadinya krisis global pada tahun 2008, sehingga faktor guncangan eksternal tersebut kami masukkan sebagai salah satu faktor yang berpotensi memengaruhi tingkat efisiensi perbankan.

Hal ini sejalan dengan penelitian yang dilakukan oleh Wolters, Couto, dan Felicio (2014), Alzubaidi dan Bougheas (2012), Forughi dan De Zoysa (2012), dan Popovici (2014). Hasil yang ditemukan mereka terkait pengaruh krisis global terhadap efisiensi perbankan cukup beragam. Signifikansi pengaruh krisis tersebut berbeda-beda baik antar negara maupun antar jenis dan status kepemilikan bank. Pada bagian kedua kajian ini akan dijelaskan data dan metodologi penelitian yang digunakan, selanjutnya hasil estimasi dan pembahasan, serta kesimpulan dan implikasi kebijakan akan dijelaskan berturut-turut pada bagian ketiga dan keempat.

\section{Data dan Metodologi \\ Data}


Jenis data yang digunakan dalam penelitian ini merupakan data panel (balanced panel data) dengan cross section sebanyak 23 bank umum lokal di kawasan ASEAN-5 selama periode 2005-2012. Selain berdasarkan ketersediaan data, 23 bank tersebut dipilih secara purposif karena bank-bank yang dimaksud merupakan bank terbesar ketiga hingga keenam di masing-masing negara. Data yang digunakan pada kajian ini merupakan data sekunder yang diperoleh dari laporan keuangan tahunan, bersumber dari publikasi resmi pada website masing-masing bank umum. Sementara data untuk beberapa indikator makroekonomi bersumber dari World Bank.

Dalam mengukur efisiensi biaya masing-masing bank, fungsi biaya yang dapat menggambarkan biaya bank perlu dirumuskan. Fungsi biaya tersebut tersusun atas variabel dependent berupa total biaya dan variabel independent antara lain variabel output (total kredit, sekuritas, dan penerimaan aset lainnya), variabel input price (biaya bunga, biaya tenaga kerja, dan biaya modal), variabel fixed netputs yaitu variabel aset tetap serta variabel eksogen yaitu return on equity (ROE), rasio ekuitas terhadap aset (ETA), Gross Domestic Product (GDP) per kapita, dan suku bunga riil. GDP per kapita yang digunakan merupakan GDP riil. Hal ini disebabkan GDP riil lebih relevan untuk membandingkan kesejahteraan relatif antar negara karena telah mempertimbangkan unsur inflasi.

Terdapat dua pendekatan umum yang digunakan untuk mengidentifikasi variabel input dan output pada suatu kajian efisiensi, yaitu: production approach yang diperkenalkan oleh Cobb dan Douglas pada tahun 1928 dan intermediation approach yang diperkenalkan oleh Sealey dan Lindley pada tahun 1977 . Pendekatan produksi mendefinisikan aktivitas b a $\mathrm{k}$ a d a l a h m e $\mathrm{m} \mathrm{p} \mathrm{r} \mathrm{o} \mathrm{d} \mathrm{u} \mathrm{k}$ $\mathrm{s}$ i j a s a d a n memandang bank sebagai pengguna tenaga kerja dan kapital untuk menyediakan jasa simpanan dan pinjaman.

Tetapi pendekatan intermediasi memandang bank sebagai intermediasi dari jasa keuangan d a n m e $\mathrm{ng}$ a s u $\mathrm{m} \mathrm{s} \mathrm{k} \mathrm{a} \mathrm{n} \mathrm{b} \mathrm{a} \mathrm{h} \mathrm{w} \mathrm{a} \mathrm{b} \mathrm{a} \mathrm{n} \mathrm{k} \mathrm{m} \mathrm{e} \mathrm{ng} \mathrm{um} \mathrm{pu}$ $1 \mathrm{k}$ a $\mathrm{n} \mathrm{s}$ i m p a $\mathrm{n}$ a $\mathrm{n}$ d e $\mathrm{n} g$ a $\mathrm{n}$ menggunakan tenaga kerja dan kapital dan menjadi perantara sumber dana tersebut untuk dijadikan sebagai pinjaman dan other earning asset. Secara praktis, pendekatan intermediasi merupakan pendekatan yang lebih luas digunakan pada kajian-kajian efisiensi perbankan (diantaranya Popovici, 2014; Alzubaidi dan Bougheas, 2012; Anayiotos, et al.,

2010; Berger dan Mester, 1997; dan Kosak, et al., 2009).

Dalam penelitian ini pendekatan yang digunakan adalah inter mediate appr oach. Sehingga variabel input yang digunakan seperti yang telah dijelaskan di atas dan salah satu output yang digunakan adalah jumlah total pinjaman dan bukan pendapatan bunga. Karena pendapatan bunga dijadikan sebagai proksi variabel output pada pendekatan produksi (lihat Dash dan Gosh).Variabel fixed net puts merupakan komponen yang tidak masuk ke dalam bisnis inti dari bank, tetapi dapat memengaruhi biaya atau pun pendapatan sehingga tidak dapat dikategorikan langsung sebagai input maupun output. Variabel fixed income dari obligasi atau pun pinjaman antar bank memang merupakan proksi yang lebih baik untuk digunakan, tetapi terdapat ketidak lengkapan data beberapa bank dari negara lain dimana laporan keuangannya tidak tersedia dalam versi detail. 
Sehingga seperti yang dinyatakan oleh Alzubaidi dan Bougheas (2012), aset tetap dianggap sebagai proksi dari capital input. Tetapi karena aset tetap tersebut bukan merupakan komponen input dari core business bank, maka variabel tersebut dimasukkan sebagai fixed netput. Sementara variabel ETA (rasio ekuitas terhadap total aset) digunakan sebagai ukuran dari solvency secara umum. Dalam kajian ini variabel tersebut digunakan untuk menentukan tingkat kesehatan finansial dan keuntungan jangka panjang dari suatu perusahaan yang dalam hal ini adalah bank. Rasio capital to risk weighted asset sebenarnya dapat digunakan sebagai variabel eksogen jika lebih fokus pada capital adequacy dan risiko bank.

Tabel 1. Definisi Operasional Variabel yang Digunakan dan Hipotesis Pengaruh

\begin{tabular}{|c|c|c|c|}
\hline Simbol & Jenis Variabel & Defmisi Variahel & Hipotesis \\
\hline C & $\begin{array}{l}\text { Variabel ak } \\
\text { bebas } \\
\text { (dependent } \\
\text { ianabisi) }\end{array}$ & $\begin{array}{l}\text { Total biaya - beban } \\
\text { bunga t beban operasional } \\
\text { Tainnya }\end{array}$ & \\
\hline $\mathbf{y}_{1}$ & & $\begin{array}{l}\text { Lasns (jumlah pinjuman yang } \\
\text { disalurkan) } \\
\text { Secsontior (umlah sekuritas }\end{array}$ & Berpengaruh prositif \\
\hline$y_{2}$ & & $\begin{array}{l}\text { atau pencrimanan asset lain } \\
\text { (surat berharga yang dimiliki) }\end{array}$ & Berpengaruh positif \\
\hline$y_{3}$ & & Other aansitg asml & Berpengaruh positif \\
\hline $\mathbf{w}_{1}$ & $\begin{array}{l}\text { Variabel } \\
\text { oncput dan } \\
\text { input }\end{array}$ & $\begin{array}{l}\text { Price of find (rasio beban } \\
\text { bunga terhadap dana pihak } \\
\text { keriga) }\end{array}$ & Berpengarah posinf \\
\hline $\mathbf{w}_{2}$ & & $\begin{array}{l}\text { Price of babor (rasio biaya } \\
\text { personala } \\
\text { tethadap total aset) }\end{array}$ & Berpengarul positif \\
\hline $\mathbf{w}_{3}$ & & $\begin{array}{l}\text { Price of capotial (rasio biaya } \\
\text { operasional lainnya terhadap } \\
\text { ast tetap) }\end{array}$ & Berpengaruh positif \\
\hline 2 & $\begin{array}{l}\text { Variabet fixed } \\
\text { whint }\end{array}$ & Aset thetap & Berperygaruh pusitif \\
\hline ROE & & $\begin{array}{l}\text { Reisin al engais (proxy } \\
\text { profitabilicas) }\end{array}$ & Berperngaruh pusitif \\
\hline ETA & & $\begin{array}{l}\text { Rasio ckuitas terhadap total } \\
\text { aset }\end{array}$ & Berpengaruh positif \\
\hline GDPCap & $\begin{array}{l}\text { Vanabel } \\
\text { cksogen }\end{array}$ & $\begin{array}{l}\text { GDP per kapita ril tahun } \\
\text { dasar } 2005\end{array}$ & Berpengaruh segatif \\
\hline INT & & $\begin{array}{l}\text { Tingkat suika bunga ril } \\
\text { Dmmon krisis, bernilai " } 1 \text { " saat }\end{array}$ & Berpengaruh positif \\
\hline Dum_cris & & $\begin{array}{l}\text { krisis global } 2008 \text { dan bernilai } \\
\text { "0" saat tidak krisis }\end{array}$ & Berpengaruh positif \\
\hline
\end{tabular}

Profitabilitas suatu bank dapat diproksi dari bererapa rasio keuangan antara lain ROE, ROA, dan NPM (Net Profit Margin). NPM mengukur tingkat 
keuntungan yang diperoleh dibandingkan dengan pendapatan yang diterima dari kegiatan operasionalnya. ROE menggambarkan kemampuan manajemen bank dalam mengelola kapital yang ada untuk mendapatkan net income. Sementara ROA mengukur kemampuan manajemen dalam memperoleh profitabilitas dan manajerial efisiensi secara keseluruhan. Tetapi beberapa peneliti menyatakan bahwa ukuran profitabilitas khususnya untuk bank lebih relevan diproksi dengan ROA dan ROE (lihat antara lain Bonin, et al., (2005), Athanasoglou, Brissimis, dan Delis (2005), Ghazali (2008), Alper dan Anbar (2011), Ali, Akhtar, dan Ahmed (2011), serta Lin dan Zhang, 2009). ROE dipilih dibandingkan ROA pada kajian ini mengingat nilai ROA dapat menjadi bias akibat aktivitas off-balance-sheet (Mirzaei, Liu, dan Moore, 2011). Tetapi ROE juga memiliki kelemahan dimana risiko terkait dengan tingginya financial leverage diabaikan.

Transformasi data ke dalam bentuk logaritma natural dilakukan untuk variabel yang jenisnya bukan rasio. Variabel yang digunakan dalam penelitian ini merujuk pada penelitian yang dilakukan oleh Kosak, et al. (2009) serta Berger dan Mester (1997) dengan beberapa modifikasi yaitu memasukkan variabel tingkat suku bunga riil (INT) yang diindikasikan memiliki hubungan dengan tingkat efisiensi biaya perbankan. Menurut Fries dan Taci (2005), semakin tinggi tingkat suku bunga akan meningkatkan beban bunga bank serta beban operasional lainnya yang pada akhirnya akan meningkatkan biaya dan menurunkan tingkat efisiensi melalui ketidakpastian dan risiko yang lebih besar.

\section{Metode Analisis}

Pengukuran tingkat efisiensi setiap bank dalam penelitian ini menggunakan model SFA dengan pendekatan time-invariant inefficiency model dan time-varying decay model. Model SFA mer upakan suatu pendekatan frontier e ko $\mathrm{n} \mathrm{o} \mathrm{m}$ i , y a n g m e $\mathrm{n}$ i 1 a i f u n g s i b i ay a, keuntungan, atau hubungan produksi sejumlah input, output, dan faktor lingkungan, serta memperhitungkan random error (Berger dan Mester, 1997).

Fungsi biaya pada model SFA terdiri dari dua bagian, yakni bagian deterministic $\mathrm{f}\left(\ln \mathrm{y}_{\mathrm{it}}, \ln \mathrm{w}_{\mathrm{it}}\right)$ dan bagian acak $\mathrm{u}_{\mathrm{it}}+\mathrm{v}_{\mathrm{it}}$. Model dasar pada pendekatan ini mengasumsikan bahwa biaya total yang dikeluarkan oleh sebuah bank berbeda dari biaya optimal karena adanya random noise $v_{i}$ dan komponen inefisiensi $u_{i}$. Merujuk pada penelitian Berger dan Mester (1997), fungsi biaya untuk bank ke-i dapat dituliskan dalam bentuk.

$$
\ln c_{i t}=f\left(\left(\ln y_{i t}, \ln w_{i t}\right)+\varepsilon_{i t}\right.
$$

dimana:

$\mathrm{C}_{\text {it }} \quad=$ biaya total dari bank ke-i padaperiode ke- $\mathrm{t}$

$\mathrm{y}_{\mathrm{it}} \quad=$ vektor kuantitas output yang dihasilkan bank ke-i pada period ke-t

$\mathrm{W}_{\mathrm{it}} \quad=$ vektor harga input dari bank ke-i pada periode ke- $\mathrm{t}$

$\varepsilon_{\text {it }} \quad=$ komponen error yang terdiri dari dua bagian dalam bentuk:

${ }^{\varepsilon}$ it $\quad=u_{i t}{ }^{+v}{ }_{i t}$

$\mathrm{v}_{\mathrm{it}} \quad=$ faktor acak yang tidak dapat dikendalikan

$\mathrm{u}_{\mathrm{it}} \quad=$ faktor error yang dapat dikendalikan (inefisiensi) 
Terdapat dua model utama yang digunakan untuk mengestimasi efisiensi, yaitu time-invariant model dan time-varying decay model.

\section{Time-Invariant Model}

Time invariant model menggunakan maximum likelihood yang mengestimasi untuk parameter time invariant model. Dalam model ini, efek inefisiensi dapat dijelaskan oleh model:

$$
\begin{gathered}
u=u_{i t} \\
\text { dimana } u_{t} \sim N+\left(\mu, \sigma_{u}\right), u_{i t} \sim N\left(0, \sigma_{u}\right)(2)
\end{gathered}
$$

Dalam model ini, $u_{i t}$ dan $u_{t}$ terdistribusi secara independen satu sama lain dan bervariasi dalam model. Dengan demikian, hasil efisiensi dari time invariant model secara umum akan menunjukkan hasil yang sama antar waktu.

Time-Varying Decay Model

Time var ying decay model meng gunakan maximum likelihood yang mengestimasi parameter time varying decay model. Dalam model ini, efek inefisiensi akan dijelaskan oleh model berikut:

$u_{i t}=\exp \left\{-\eta\left(t-T_{t}\right)\right\} u_{i}$

$$
\text { dimana } u_{i} \sim N+\left(\mu, \sigma_{u}^{2}\right)
$$

Saat $\eta>0$, derajat inefisiensi akan menurun seiring waktu. Saat $\eta<0$, maka derajat inefisiensi akan meningkat seiring waktu. Karena $\mathrm{t}=\mathrm{Tt}$ di periode terakhir, maka periode terakhir produsen i mengandung level dasar dari inefisiensi untuk produsen itu. Jika $\eta>0$, level inefisiensi akan hilang selama level dasar. Jika $\eta<0$, level inefisiensi akan meningkat ke level dasar. Dengan demikian, hasil efisiensi time varying decay model akan menunjukkan perbedaan antar waktu. Model inilah yang digunakan pada penelitian ini.

\section{Efisiensi Biaya}

Efisiensi biaya dari sebuah bank, misalnya bank A, didefinisikan sebagai estimasi biaya yang dibutuhkan untuk memproduksi suatu set (vektor) output dari bank A jika bank A tersebut beroperasi secara efisien dengan menggunakan variabel eksogen yang sama ( $w, y, z, v)$ dibandingkan dengan biaya aktual yang dikeluarkan. Secara matematis efisiensi biaya bank dapat mengikuti perhitungan yang dilakukan Berger dan Mester (1997) dengan rumus:

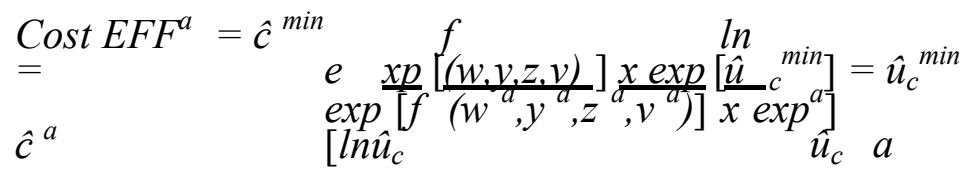

Biaya minimum ( $\hat{\mathbf{c}})$ tersebut mengindikasikan minimum (optimal) cost untuk seluruh sampel bank, sehingga hal ini menunjukkan frontier dari sampel $(\mathrm{Cb}=$ biaya aktual dari bank A). Cost EFF merupakan proporsi dari biaya atau resources yang digunakan secara efisien (misalkan rasio cost efficiency suatu bank sebesar 80 persen, hal ini menunjukkan bahwa bank tersebut beroperasi secara efisien sebesar 80 persen atau terdapat 20 persen biaya yang terbuang). 
Efisiensi biaya akan berkisar dalam interval $(0,1]$ dengan nilai efisiensi satu menunjukkan bank tersebut merupakan bank yang paling efisien.

\section{Hasil dan Pembahasan}

Tabel 2 merupakan nilai rataan variabel-variabel output, input, dan netput yang digunakan dalam penelitian ini. Penggunaan variabel tersebut mengikuti penelitian yang dilakukan oleh Kosak, et al. (2009) dengan beberapa modifikasi data.

Tabel 2. Nilai Rataan Variabel Output, Input, dan Fixed Netputs

\begin{tabular}{|c|c|c|c|c|c|c|}
\hline Variabel & Unit & Indonesia & Singapura & Malaysia & Thailand & Filipina \\
\hline C & $\begin{array}{l}\text { Rp. } \\
\text { Milyar }\end{array}$ & $16,083.16$ & $34,376.19$ & $14,419.19$ & $15,225.43$ & $6,214.55$ \\
\hline $\mathrm{y} 1$ & $\begin{array}{l}\text { Rp. } \\
\text { Milyar }\end{array}$ & $127,020.20$ & $774,579.90$ & $233,657.40$ & $283,751.70$ & $58,314.87$ \\
\hline y2 & $\begin{array}{l}\text { Rp. } \\
\text { Milyar }\end{array}$ & $48,667.47$ & $227,725.30$ & $65,124.92$ & $55,815.14$ & $28,959.65$ \\
\hline y3 & $\begin{array}{l}\text { Rp. } \\
\text { Milyar }\end{array}$ & $22,420.43$ & $134,680.10$ & $9,227.42$ & $38,204.18$ & $17,571.36$ \\
\hline w1 & $\%$ & 5.03 & 2.12 & 2.66 & 2.07 & 2.55 \\
\hline w2 & $\%$ & 1.92 & 0.56 & 0.73 & 0.96 & 1.28 \\
\hline $\mathbf{w}_{3}$ & $\%$ & 177.92 & 87.81 & 150.40 & 41.07 & 65.87 \\
\hline 7 & $\begin{array}{l}\text { Rp. } \\
\text { Milyar }\end{array}$ & ) 88751 & $11121 \mathrm{no}$ & $\int 1 \cap 582$ & 12396.22 & $282 \cap 17$ \\
\hline
\end{tabular}

Keterangan: $\mathrm{C}=$ total biaya; $\mathrm{y}_{1}=$ total kredit; $\mathrm{y}_{2}=$ total sekuritas; $\mathrm{y}_{3}=$ penerimaan aset lainnya; $\mathrm{w}_{1}=$ biaya pendanaan (cost of fund); $\mathrm{w} 2=$ biaya tenaga kerja (cost of labour); $\mathrm{w}_{3}=$ biaya modal (cost of capital); $\mathrm{z}=$ aset tetap.Catatan: nilai dalam mata uang valuta asing diubah ke dalam bentuk rupiah dengan menggunakan kurs tengah Bank Indonesia.

Pengukuran efisiensi biaya perbankan lintas negara tidak cukup mengandalkan informasi dari kinerja bank itu sendiri. Perbedaan kondisi masingmasing negara seperti kebijakan dari otoritas terkait, kepemilikan bank, bahkan nasabah bank dapat menyebabkan perbedaan efisiensi bank-bank tersebut (Kosak, et al. 2009).

Oleh karena itu, penelitian ini menganalisis efisiensi bank-bank di kawasan ASEAN dengan menggunakan variabel eksogen yaitu return on equity (ROE), suku bunga riil (INT), pendapatan/GDP per kapita (GDPCap), dan rasio ekuitas terhadap total aset (ETA).

\section{Tingkat Efisiensi Bank dan Faktor-faktor yang Memengaruhinya}

Hasil estimasi fungsi biaya untuk sampel bank di kawasan ASEAN-5 selama periode 2005-2012 tersaji pada Tabel 3. Hasil estimasi yang digunakan dalam penelitian ini menggunakan pendekatan time-varying decay. Secara umum hasil 
estimasi dari model SFA menunjukkan hasil yang cukup baik, terlihat dari nilai statistik uji Wald (Wald Chi-sq) di atas menunjukkan bahwa model tersebut sudah baik karena memiliki nilai probabilitas kurang dari $\alpha=5 \%$. Dilihat dari tingkat signifikansi koefisien parameter juga sebagian besar signifkan pada taraf nyata 5\% (berdasarkan nilai statistik uji-t). Pada model time-varying decay model ini terlihat bahwa hampir semua variabel-variabel yang digunakan dalam penelitian ini berpengaruh signifikan, kecuali variabel biaya tenaga kerja, ETA, GDP per kapita, dan suku bunga riil.

Variabel-variabel output sesuai hipotesis memiliki tanda koefisien yang positif. Koefisien total kredit (y1) yang diperoleh dari hasil estimasi sebesar 0.512 , artinya jika terjadi kenaikan kredit yang disalurkan oleh bank sebesar $1 \%$ diduga akan meningkatkan total biaya sebesar $0.512 \%$, cateris paribus. Peningkatan total kredit yang disalurkan pada dasarnya sebagai salah satu indikator perkembangan setiap bank. Peningkatan total kredit ini diharapkan tidak akan meningkatkan jumlah kredit bermasalah. Untuk menjaga agar non performing loan (NPL) tidak meningkat, maka bank har us meningkatkan biaya monitoring dan biaya pengelolaan risiko untuk menjaga tingkat NPL-nya. Hal ini sesuai dengan salah satu hubungan antara kredit dengan efisiensi yang berlandaskan pada masalah moral hazard dan informasi asimetris (Berger dan De Young, 1997). Begitupun dengan variabel output lainnya yaitu total sekuritas dan penerimaan aset lainnya yang memiliki hubungan positif dengan total biaya.

Tetapi, koefisien yang didapat lebih rendah daripada koefisien total kredit, dimana hal ini sejalan dengan kajian Kosak, et al. (2009). Hasil ini relevan mengingat dari tiga komponen output tersebut, total kredit memiliki nilai terbesar.

Tabel 3. Hasil Estimasi Fungsi Biaya dengan Menggunakan Metode SFA

\begin{tabular}{|c|c|c|}
\hline \multirow{2}{*}{$\begin{array}{l}\text { Variabel } \\
\text { Independen }\end{array}$} & \multicolumn{2}{|c|}{ Time-V arying Decay Model } \\
\hline & Coef. & Std. Err. \\
\hline $\ln y_{1}$ & $0.512 * *$ & 0.050 \\
\hline $\ln y 2$ & $0.096^{* *}$ & 0.028 \\
\hline $\ln y 3$ & $0.053 * *$ & 0.014 \\
\hline $\mathrm{W} 1$ & $0.137 * *$ & 0.011 \\
\hline w2 & 0.060 & 0.037 \\
\hline W3 & $0.002 * *$ & 0.000 \\
\hline $\ln z$ & $0.195^{* *}$ & 0.034 \\
\hline eta & 0.005 & 0.006 \\
\hline roe & $0.004 * *$ & 0.002 \\
\hline lngdpcap & 0.012 & 0.041 \\
\hline int & 0.005 & 0.003 \\
\hline dum_cris & $0.073^{* *}$ & 0.024 \\
\hline konstanta & 2.062 & 1.195 \\
\hline Wald Chi-sq & 1829.34 & \\
\hline Prob. & 0.0000 & \\
\hline Loglikelihood & 147.55559 & \\
\hline$n$ & 0.058 & \\
\hline
\end{tabular}


Sementara itu, dari sisi variabel input juga menunjukkan hal yang sama. Variabel input memiliki pengaruh yang positif terhadap total biaya, tetapi hanya rasio cost of fund dan cost of capital. Variabel rasio beban bunga terhadap dana pihak ketiga $\left(\mathrm{w}_{1}\right)$ memiliki koefisien estimasi tertinggi yaitu 0.137, artinya apabila terjadi kenaikan rasio tersebut sebesar 1\% diduga akan meningkatkan total biaya yang harus dikeluarkan oleh bank sebesar $0.137 \%$, cateris paribus. Peningkatan pada masing- masing biaya input ini tentunya akan meningkatkan total biaya yang dikeluarkan dan pada akhirnya akan menurunkan tingkat efisiensi biayanya, cateris paribus.

Cost of funds merupakan tingkat suku bunga yang harus dibayarkan suatu lembaga keuangan atas dana yang mereka dapatkan. Nilai koefisien dari variabel ini lebih besar dari koefisien variabel biaya modal. Hal ini sesuai dengan ekspektasi dimana cost of fund merupakan biaya input yang paling penting untuk lembaga keuangan seperti bank. Cost of fund yang lebih rendah akan menurunkan total biaya secara keseluruhan, yang pada akhirnya akan menghasilkan tingkat pengembalian yang lebih baik. Hasil ini sejalan juga dengan kajian Kosak, et al. (2009) dimana koefisien input berupa cost of fund memiliki nilai yang lebih besar dibandingkan dengan koefisien dua input lainnya.

Variabel fixed netput yang digunakan dalam penelitian ini yaitu aset tetap berpengaruh secara signifikan terhadap total biaya. Hasil estimasi menunjukkan koefisien aset tetap (lnz) memiliki tanda positif. Jika terjadi peningkatan aset tetap maka total biaya akan meningkat, dengan demikian menurunkan tingkat efisiensinya. Hal ini disebabkan karena peningkatan aset tetap suatu bank akan meningkatkan biaya operasional seperti biaya perawatan atau biaya tetap sehingga akan meningkatkan total biaya yang har us ditanggung oleh bank sehingga efisiensi biaya akan menurun.

Variabel makroekonomi yang digunakan dalam penelitian ini yaitu tingkat suku bunga riil (INT) dan GDP per kapita tidak berpengaruh signifikan terhadap total biaya. Dengan kata lain, variabel yang mewakili unsur lingkungan tempat bank beroperasi tidak memengaruhi tingkat efisiensi bank-bank di ASEAN. Hasil ini memiliki kesamaan dengan penelitian yang dilakukan Fries dan Taci (2005), khusus untuk tidak signifikansinya variabel GDP per kapita. Sementara itu, variabelvariabel karakteristik bank yaitu rasio ekuitas terhadap total biaya (ETA) tidak berpengaruh signifikan tetapi retur $\mathrm{n}$ on equity (ROE) berpeng ar uh signifikan terhadap total biaya.

Variabel ROE berpengaruh positif dengan koefisien yang diperoleh sebesar 0.004 . Return on equity mengukur seberapa banyak keuntung an sebuah per usahaan yang dihasilkan dari ekuitas pemegang saham. ROE yang lebih tinggi menunjukkan profitabilitas yang lebih tinggi. Profitabilitas yang lebih tinggi mengindikasikan efisiensi biaya yang juga lebih tinggi. Karena profit yang lebih ting gi salah satunya bisa berarti pada manajemen pengeluaran bank yang lebih baik. Hubungan ROE yang positif dengan tingkat efisiensi yang ditemukan pada kajian ini sejalan dengan temuan Berger dan Mester (1997).

Selain itu, penelitian ini juga menggunakan variabel dummy untuk melihat pengaruh krisis global yang terjadi pada tahun 2008. Hasil estimasi pada Tabel 3 menunjukkan bahwa variabel dummy berpengaruh signifikan dan memiliki 
hubungan positif dengan total biaya. Dengan kata lain, hal ini berarti bahwa krisis yang terjadi secara umum menurunkan tingkat efisiensi bank-bank di ASEAN-5. Untuk kasus di negara berkembang di Eropa, Anayiotos, Toroyan, dan Vamvakidis (2010) menemukan hal yang serupa, dimana selama krisis tingkat efisiensi bank menurun secara signifikan.

Tabel 4. Nilai efisiensi bank-bank di kawasan ASEAN-5 menggunakan pendekatan timevarying decay model

\begin{tabular}{llll}
\hline Kode Bank & Nilai efisiensi & Kode Bank & $\begin{array}{l}\text { Time-varying } \\
\text { decay }\end{array}$ \\
\hline 15 & 0.846 & 32 & 0.689 \\
42 & 0.790 & 35 & 0.685 \\
41 & 0.789 & 33 & 0.684 \\
43 & 0.781 & 52 & 0.661 \\
45 & 0.766 & 51 & 0.654 \\
16 & 0.759 & 54 & 0.647 \\
44 & 0.758 & 13 & 0.579 \\
22 & 0.758 & 12 & 0.575 \\
21 & 0.757 & 31 & 0.559 \\
34 & 0.725 & 14 & 0.519 \\
11 & 0.701 & 53 & 0.514 \\
23 & 0.693 & & \\
\hline
\end{tabular}

Sumber: Hasil Pengolahan Catatan: Nama bank tidak ditampilkan sesuai dengan etika penelitian.

Hasil estimasi dengan pendekatan time-varying decay menghasilkan $\eta$ (dibaca: eta). Variabel tersebut dapat memberikan gambaran efisiensi dari bank-bank tersebut apakah mengalami peningkatan atau penurunan selama kurun waktu periode penelitian (Battese dan Coelli, 1993). Pada Tabel 3 parameter estimasi $\eta$ pada fungsi biaya bernilai 0.058 (positif) artinya dalam penelitian ini terjadi peningkatan efisiensi biaya selama periode penelitian. Dari hasil estimasi tersebut dijelaskan bahwa telah terjadi perubahan tingkat efisiensi pada bank-bank di kawasan ASEAN5 yaitu cenderung meningkat.

Nilai efisiensi masing- masing bank berdasarkan hasil estimasi dengan pendekatan time-varying decay model dapat dilihat pada Tabel. 4Semakin tinggi nilai efisiensi suatu bank menunjukkan bahwa semakin efisien bank tersebut mengelola faktor input yang digunakan (relatif terhadap bank lain). Dengan menggunakan pendekatan time-varying decay model, terdapat masing-masing 6 bank dengan status tidak efisien $(\mathrm{NE}<0.651)$, cukup efisien $(0.693<\mathrm{NE}<$ $0.759)$, dan efisien ( $\mathrm{NE}>0.759$ ). Sisanya (5 bank) memiliki status kurang efisien $(0.651<\mathrm{NE}<0.693)$.

Dari hasil perhitungan nilai efisiensi masing-masing bank kemudian dihitung nilai efisiensi masing-masing negara sehingga diharapkan mampu menggambarkan kondisi efisiensi perbankan tiap negara. Nilai efisiensi yang 
dihasilkan merupakan nilai rata-rata dari nilai efisiensi bank-bank yang beroperasi di masing-masing negaranya. Tabel 5 menyajikan perbandingan nilai efisiensi biaya perbankan di masing-masing negara.

Tabel 5. Perbandingan Nilai Efisiensi Perbankan ASEAN-5

\begin{tabular}{ll}
\hline Negara & Tin $e$-vary ing decoy \\
\hline Indoncsia & 0.663 \\
Singapura & 0.736 \\
Malaysia & 0.669 \\
Thailand & 0.777 \\
Filipina & 0.619 \\
\hline
\end{tabular}

Sumber: Hasil Pengolahan

Nilai efisiensi biaya tertinggi dimiliki oleh perbankan Thailand dengan rata-rata nilai efisiensi sebesar 0.777 pada pendekatan time-varying decay. Besarnya nilai tersebut menunjukkan bahwa perbankan Thailand beroperasi secara efisien sebesar $77.7 \%$ atau terdapat $22.3 \%$ efisiensi biaya yang masih bisa dimanfaatkan oleh perbankan Thailand. Sementara itu, perbankan Indonesia memiliki rata-rata efisiensi biaya sebesar 0.663 , artinya perbankan Indonesia hanya mampu beroperasi secara efisien sebesar $66.3 \%$ atau terdapat $33.7 \%$ efisiensi biaya yang masih bisa dimanfaatkan oleh perbankan di Indonesia. Perbankan Filipina memiliki efisiensi biaya terendah di kawasan ASEAN-5 dengan rata- rata sebesar 0.619, artinya perbankan Filipina beroperasi secara efisien sebesar $61.9 \%$ atau terdapat $38.1 \%$ efisiensi biaya yang masih bisa dimanfaatkan oleh perbankan Filipina.

\section{Penutup}

Hasil estimasi dengan menggunakan metode SFA dalam penelitian ini dapat disimpulkan bahwa secara umum bank-bank di kawasan ASEAN-5 beroperasi cukup efisien dengan rata-rata nilai efisiensi 71.84\%. Dalam penelitian ini bank-bank Thailand memiliki nilai efisiensi tertinggi diikuti Singapura, Malaysia, Indonesia, dan Filipina. Variabel- variabel yang digunakan untuk mengukur tingkat efisiensi perbankan di kawasan ASEAN-5 hampir seluruhnya berpengaruh secara signifikan. Variabel output, input, dan fixed netput memiliki memiliki pengaruh positif terhadap total biaya.

Variabel karakateristik bank yaitu ROE berpengaruh signifikan terhadap total biaya, sedangkan variabel ETA tidak berpengaruh signifikan terhadap total biaya. Variabel makroekonomi yang digunakan dalam penelitian ini tidak ada yang berpengaruh signifikan pada total biaya.

Secara umum, hasil kajian ini menunjukkan bahwa bank-bank di Indonesia belum beroperasi secara efisien jika dibandingkan dengan bank-bank di empat negara lainnya. Dalam kaitannya denganimplementasi ASEAN Economic Community (AEC) tentu hal ini menjadi tantangan yang begitu besar bagi pemerintah, Bank Indonesia, dan Otoritas Jasa Keuangan. Meskipun efisiensi bukan satu-satunya ukuran kinerja perbankan, tetapi jika kinerja indikator tersebut tidak diperbaiki tentu dapat memengaruhi daya saing bank-bank 
Indonesia terutama di kawasan regional ASEAN. Kebijakan pengembangan keuangan inklusif yang salah satunya didukung melalui pengembangan branchless banking saat ini menjadi relevan. Branchless banking menjadi salah satu strategi dalam menur unkan overhead cost dan connectivity cost (Pickens, Porteous, dan Rotman, 2009). Sehingga BI dan OJK harus terus menggalakan peningkatan penerapan branchless banking kepada bank-bank dan menyempurnakan semua perangkat pendukungnya termasuk aturan-aturan terkait. $\mathrm{H}$ a $\mathrm{l}$ i $\mathrm{n} \mathrm{i} \mathrm{d} \mathrm{i} 1$ a k u k a n $\mathrm{u} \mathrm{n} \mathrm{t} \mathrm{u} \mathrm{k} \mathrm{m} \mathrm{e} \mathrm{m} \mathrm{b} \mathrm{a} \mathrm{n} \mathrm{t} \mathrm{u} \mathrm{memperbaiki} \mathrm{tingkat} \mathrm{efisiensi} \mathrm{bank} \mathrm{yang} \mathrm{pada} \mathrm{akhirnya}$ dapat meningkatkan daya saing bank-bank di Indonesia terutama bank domestik di kancah regional bahkan internasional.

Selain melihat indikator makro yang memengaruhi tingkat efisiensi bank, struktur kepemilikan bank dan persaingan antar bank di $\mathrm{m}$ a s i $\mathrm{ng}-\mathrm{m}$ a s i $\mathrm{ng} \mathrm{n}$ e $\mathrm{g}$ a $\mathrm{r}$ a d a $\mathrm{p}$ a $\mathrm{t} \mathrm{d}$ i c o b a ditambahkan seperti yang dilakukan oleh Bonin, et al. (2005). Karena hasil kajiannya menunjukkan terdapat tingkat efisiensi yang berbeda antar bank yang memiliki perbedaan struktur kepemilikan (asing atau domestik). Bank-spesific determinant juga dapat ditambahkan pada kajian berikutnya selain ROE yang digunakan pada kajian ini.

\section{Referensi}

Ali K., Akhtar, M.F., \& Ahmed, H.Z. (2011). Bank-Specific and Macroeconomic Indicators of Profiability - Empirical Evidence from The Commercial Banks of Pakistan. International Journal of Business and Social Science, 2(6), 235-242.

Alper, D, \& Anbar, A. (2011). Bank Specific and Macroeconomic Determinants of Commercial Bank Profitability : Empirical Evidence from Turkey. Business and Economics Research Journal, 2, 139-152.

Alzubaidi, H., \& Bougheas, S. (2012). The Impact of the Global Financial Crisis on European Banking Efficiency. CFCM Working Paper, No. 12/05: 1-31.

Anayiotos, G., Toroyan, H., \& Vamvakidis, A. (2010). The Efficiency of Emerging Europe's Banking Sector Before and After the Recent Economic Crisis. Financial Theory and Practice, 34(3), 247- 267.

Athanasoglou, P.P., Brissimis, S.N. , \& Delis M.D.(2005). Bank-specific, Industry-Specific and Macroeconomic Determinants of Bank Profitability. Bank of Greece Working Paper No. 25.pp.4-35.

Banerjee, B. (2012). Banking Sector Efficiency in New EU Member States: A Survey of Cross Countr y Evidence. Easter $n$ European Economics, 7(6), 81-115. DOI: 10.2753/EEE0012-8775500604

Battese, G.E., \& Coelli, T.J.(1993). A Stochastic Frontier Production Function Incorporating A Model for Technical Inefficiency Effects. Working Paper 
cat the Australasian Meeting of the Econometric Society at the University of Sydney, 7-9 July 1993.

Battese, G.E, \& Coelli, T.J (1995). A Model for Technical Inefficiency Effects in a Stochastic Frontier Production Function for Panel Data. Empirical Economics, 20, 325-332.

Berger, A.N., \& De Young R.(1997). Problem Loans and Cost Efficiency in Commercial Bank. Journal of Banking and Finance, 21(6), 849-870.

Berger, A.N., \& Mester, L.J. (1997). Inside the Black Box : What Explains Differences in the Efficiencies of Financial Institutions?. Journal of Banking and Finance, 21, 895-947.

Bonin, J.P., Hasan, I., \& Wachtel, P. (2005). Bank Performance, Efficiency and Ownership in Transition Countries. Journal of Banking and Finance, 29, 31-53.

Das A., \& Ghosh, S. (2006). Financial deregulation and efficiency: An empirical analysis of Indian banks during the post reform period. Review of Financial Economics, 15 (3), 193-221. 